\title{
FROM THE VILLAGES TO THE CITIES: the battlegrounds for Lepcha protests
}

\author{
Transforming Cultures eJournal, \\ Vol. 5 No 1 June 2010 \\ http://epress.lib.uts.edu.au/journals/TfC
}

\section{Kerry Little ${ }^{1}$}

\begin{abstract}
Lepchas are the Indigenous people of Sikkim, a small Himalayan state in northeast India. They are known for their deep knowledge of botany and ecology; their close connection to their landscape has been acknowledged and admired for centuries. Their feeling for nature and reluctance to accept change to their sacred landscape, contributed to a protest movement to stop the development of several mega hydro-electric projects inside the Lepcha Dzongu Reserve in North Sikkim.
\end{abstract}

The Lepcha activists' battle to stop the hydro projects started in Dzongu villages in 2003 and relocated to the capital of Sikkim, Gangtok in June 2007. BhutiaLepcha (BL) House, a worn out building on Tibet Road in Gangtok became the site of their flagship protest, a relay hunger strike which ran for close to two and a half years. The protest also extended to the Lepcha enclave in neighbouring West Bengal and the city of New Delhi where the activists spread their protest narrative to the wider Lepcha community, NGOs and the Indian Central government. In 2008 the Lepcha activists, aware that they needed to re-engage their community, started to shift their campaign back to the villages.

This paper analyses the Lepcha protest narrative, contextualising it in terms of cultural heritage and contemporary political economy. It evaluates the protest group's strategic use of both rural and urban settings to strengthen the impact of their campaign.

\footnotetext{
${ }^{1}$ University of Technology, Sydney
} 


\section{Introduction}

"I went to Gangtok. Lots of people came and took photographs. There was a big building. I have been to that place and performed one puja...wasn't a real big one. True bongthing when performing puja usually has an animal sacrifice. In Gangtok it was simple with fruits." Atuk Lepcha aged 85 also known as "The Tarang Bongthing'.

This is a village story. Its genesis is in the remote Lepcha reserve, Dzongu in North Sikkim in northeast India. It was once a quiet story, a slow moving tale of a place and its people who were gradually shifting from a traditional life as hunters and cardamom farmers to a modern life. The young generation of Lepchas - the 'first educated generation' as they refer to themselves - are studying, working and living outside their Lepcha land. Many live in Gangtok and work in government jobs. Others study in the large Indian cities of New Delhi, Kolkata and Mumbai. Some are eager for a new, faster, contemporary lifestyle. Many are content with the slow-moving pace in the village.

A few years ago there was a turning point in the story. It came from the cities of New Delhi and the capital of Sikkim, Gangtok, with government policy in the form of the Indian Government's 50,000 MW Hydroelectric Initiative; ${ }^{3}$ a program of dam construction designed to create another 200 billion cubic metres of storage [in India]. (Dharmadhikary 2007:28) The plan includes many dams in India's north-east. In Sikkim there are currently more than 20 dams forecast or in progress, several on the Teesta River which flows through Dzongu. They are hailed by the state government as the saviour of Sikkim, the path to economic independence; for Sikkim is heavily dependent on the central government for funding.

With the announcement of the projects on the Teesta River, the story shifted from New Delhi and Gangtok to the villages in Dzongu in North Sikkim where, in 2004, a group of Lepcha youth opposed to the dams formed a 17 member group called Affected Citizens of Teesta, known as ACT. (The Telegraph 2004)

Over the next few years, the protest shifted back from the villages to the cities. A 'David and Goliath' battle had begun and the Lepchas had to defy their small numbers,

\footnotetext{
${ }^{2}$ A bongthing is a Lepcha shaman. The Tarang Bongthing was interviewed by Kerry Little at Tarang in Lower Dzongu, North Sikkim, 7 January 2009.

3 The 50,000 MW Hydroelectric Initiative was launched by the Prime Minister of India in May, 2003. 162 hydroelectric schemes have been identified with an aggregate installed capacity of 50,560 MW. They are located in sixteen Indian states. Go to http://www.powermin.nic.in for more information
} 
reputation for timidity and lack of funding to fight it. At the start it looked likely that the battle would be swift and painless for the city-based governments and private investors who sought a future for Dzongu as a hydro-energy development site. But as in the fable of the giant and the boy, the path to victory depended on more than scale and fear. The Lepcha activists - who, incidentally, like 'David' had mastered the art of sling-shot shooting as boys - would prove to be formidable representatives for the land of their birth.

Lepchas were the first inhabitants of the lands along the Himalayan mountain seam that connects north-east India, Bhutan, Tibet and Nepal. They live in Sikkim and its borderlands including the Darjeeling district of West Bengal (which includes Kalimpong and Kurseong), the Ilam district of Nepal and pockets of west and southwest Bhutan. There are approximately 45,000 Lepchas in Sikkim (State Socio Economic Census 2006:61) and 70,000 ${ }^{4}$ outside Sikkim. They have a shared history, language, and traditions and like other indigenous people who are a minority in the land they live in, they share the struggle to retain their identity against the influence of more dominant cultures, in particular Nepali culture in Sikkim and West Bengal and Bhutanese culture in Bhutan. They are widely known for their deep knowledge of botany and ecology and describe themselves as Mutanchi Rong Cup meaning Beloved Children of Mother Nature. In Sikkim where much of this story unfolds, Lepchas make up 7.8\% of the state's population of 581,500 (State Socio Economic Census 2006: 61) however, in the sparsely populated north, where the Dzongu Lepcha Reserve is located; they are $37.47 \%$ - the majority - of the population. The 7000 inhabitants of Dzongu are almost all Lepcha.

The Lepchas are protesting the dams on many grounds: that as nature-worshippers their land is sacred and should not be destroyed by development; that Dzongu is recognised as a reserve ${ }^{5}$, and since only Lepchas who are from there are allowed to enter the reserve without a special permit from the government, it should not be the site for the hydro projects. They also argue that the projects will bring several thousand workers

\footnotetext{
${ }^{4}$ It is difficult to ascertain the true number of Lepchas for people with one Lepcha parent, or grandparent may or may not identify as Lepcha. The numbers given therefore are official numbers but cannot be verified beyond their source.

${ }^{5}$ Dzongu was declared a Lepcha reserve in 1957 by the last Chogyal of Sikkim in recognition that it is the Lepcha's sacred land and should be preserved for Lepchas.
} 
from outside Sikkim into Dzongu for many years while work is completed who will outnumber the Lepcha population and, since the migrant workers have different customs and beliefs, their dominant presence will soon dilute and destroy Lepcha culture.

The protest is also on environmental grounds, the Lepcha activists claiming that the delicate ecology of Dzongu, which is partially inside Mount Kanchenjunga national park and part of the Himalaya biodiversity hotspot, ${ }^{6}$ is, like the rest of Sikkim prone to landslides and earthquakes, and will not survive the development. This claim is supported by MK Pandit, director of the Centre for Interdisciplinary Studies of Mountain and Hill Environment (CISMHE) who warned that many of the hydropower projects on the Teesta River are located in the high-risk zone IVG of the seismic zoning map. (Arora 2008:28)

My work involves recording traditional and contemporary Lepcha stories and examining how modernity and globalisation has impacted on Lepchas' connection to their traditions.

My introduction to Affected Citizens of Teesta was through two committee members, Dawa Lepcha, a filmmaker who has documented Lepcha traditions and Sherap Lepcha, best known throughout Sikkim as a talented footballer who played in the Indian National League. Together with Pemzang Lepcha, a US educated engineer, they started the grass roots campaign to fight the projects.

After meeting Sherap and Dawa, my recording of Lepcha narratives were most often in the context of the Lepcha protest against the hydro-electric projects. I have been recording the contemporary stories of the young protesters, for example, alongside the traditional stories of Lepcha elders. At times the narratives are intertwined for the protestors are mining their mythology to prove their 'sacred' ownership and allegiance to their land: their traditional stories and beliefs are a significant part of the Lepcha activists' protest narrative.

This paper explores the role of the city and the village as battlegrounds in the Lepchas' campaign to save their remote Dzongu and their culture from being destroyed by the mega-hydro projects. In order to attract attention and broaden support for their protest, the activists had to leave their farms and their families and move to Gangtok. Without

\footnotetext{
${ }^{6}$ http://www.biodiversityhotspots.org/xp/Hotspots/himalaya/Pages/default.aspx Accessed 27 Sept 2007
} 
the city, which created a centre for support, infrastructure, media and government attention, and a link to influencers in New Delhi, the Lepchas protest in all likelihood would have dwindled and died. However as the movement matured, the geographical base of the protest moved from the city, back to Dzongu in recognition of the importance of the village in gaining community support.

\section{The battle for Dzongu starts in the villages}

In the first three years much of the Lepcha protest was confined to Dzongu villages. It was a time for establishing, and communicating and finding like-minded people who shared a vision for Dzongu that did not include major infrastructure development. It was during this period the Lepcha activists' protest narrative - which encompassed culture, environment and faith - evolved.

The Lepchas' protest narrative draws on the pre-capitalist village community as an ideal of social and ecological harmony, (Baviskar1997:43) and criticises the advance of capitalism at the cost of their land and culture. The activists maintain they support smaller projects that offer employment to local communities and less impact on the environment. When discussing the issue with the media Sherap Lepcha said: ACT is "not against hydel power projects...small hydel power projects can be taken up as they do not affect the environment and the local people on a huge scale." (the Statesman 2006) This continues to be ACT's position - that they welcome small hydro projects that serve the immediate community.

The movement first started in 2003 when Lepchas opposing the Dzongu projects started holding small meetings in the villages. They formalised these meetings in July 2004, when they formed, Affected Citizens of Teesta, (ACT). Their aim at that time was to fight the large Teesta River hydro-electric projects slated for Dzongu (The Telegraph 2004) and to bring awareness to the Lepcha community of what they considered to be the harmful effects of the projects.

Back then ACT members walked from village to village to garner support. There wasn't any mobile phone coverage in Dzongu and much of the community engagement was conducted by foot with vehicles occasionally used to transport supporters to 
meetings. As mobile coverage increased so did the activists' ability to mobilise. Dawa Lepcha, who is the general secretary of ACT explained: "We had to do a lot of networking at that time. We had the volunteers in the villages, groups of boys and girls going around and we had to hire some vehicles to bring people [to meetings] ... so that's how we did it and those neighbouring villagers they would just come walking and others they would come if we hired a vehicle.... [Mobile phone] is one way we always keep contact, send messages, use the mobile and of course it has made it very convenient for us in that way. Before there was only BSNL covering a few places but now Airtel is there, Vodafone is there." 7

In January 2006, when the state government commenced a land survey with a view to acquiring land, the group held a major protest meeting in Mangan, the capital of North Sikkim.

Later that year, in June, ACT voiced concerns at the public hearing of the Teesta Stage III 1200 MW project saying that the environmental impact assessment was poorly prepared and violated the environmental, cultural, religious and social sentiments of the people. Undaunted, the government continued with the projects, granting clearance for the project before the impact assessment was completed.(TheTelegraph 2007) On September 4, 2006 the protesters blocked the road into Dzongu at the Sankalang Bridge $^{8}$ to prevent officials from the forest department and project developers entering the area for an inspection. They were arrested but later released however the action brought blanket media coverage in Gangtok and raised the profile of ACT.

According to Pema Wangchuk, the editor of the influential Sikkim English language daily newspaper NOW!, before the September 42006 protest ACT was seen as:

...an elitist group of educated Lepcha youth with a romanticised idea of development and culture which was out of sync with the more immediate aspirations for development of the people. On that day, ACT established that it also had support among the lay people when it managed to mobilize a 100strong group of protesters to lay siege on the Sankalang bridge over Teesta, the only access to Dzongu from North Sikkim, and refuse access to a jointinspection team of district officials from entering the Lepcha reserve to survey the lands. (Wangchuk 2007:35)

\footnotetext{
${ }^{7}$ Dawa Lepcha spoke to Kerry Little on 3 Jan 2009.

${ }^{8}$ Sangkalang Bridge is a check-point and border of Dzongu
} 
The Sankalang bridge protest showed the activists that they could mobilise and mount a credible protest. It gave them strength and confidence and served as an early warning to the state government and private developers that there was a battle brewing for the control of the wild waters of the Teesta in the Dzongu reserve.

\section{Different views on the future of Dzongu}

Unlike tribals elsewhere whose land has been appropriated for hydro development, the Lepchas are not facing mass displacement as the Dzongu reserve is sparsely populated, the land required for the dams is not the entire reserve, and the land acquisition is voluntary. Opposition to the dams is not inclusive of the entire Dzongu community as these projects will not force people from their homes which have been the case with dams in West Bengal and elsewhere in Sikkim.

116 landowners have sold land for the Panan 280 MW project, however not all gave their land voluntarily. Opponents of the projects claim that landowners have been tricked into selling their land. "They made us sign documents which we did not know were for selling our lands," said Passang Lepcha, a landowner from Sakyong. (Zulca 2007:7) However other landowners say they sold their land willingly. At a meeting of 300 Dzongu residents at Namprikdang in the Dzongu (8 Jul 07), landowners stressed that none of them had been forced into parting with their lands and added that even they were concerned about the environment and culture and had ensured adequate safeguards to protect them. (Sharma 2007:1)

The Lepcha community in Dzongu is divided in their views on the development and the gap between Lepchas that do or don't oppose the projects has widened over time. Relationships between friends and family members have in some villages fractured.

"Dzongu isn't what it used to be. Our families are fighting each other," said Gyatso Lepcha, [a young anti-dam activist from Passingdang, the site of the 280MW Panan project.] "When my uncle who is pro-projects walks by, we don't even look at each other. It's painful." (Mitra 2008)

The authorities adopt a divisive 'anti-national' rhetoric when describing those opposed to the projects. At a public hearing (Sep 18, 2006) conducted by Sikkim's State 
Pollution Control Board (SPCB) a woman identifies herself as the Chairperson appointed by the government to the SBCB. She shouts in anger: "Anyone who disturbs this project is not a Sikkimese. He might be born in Sikkim but is a useless person if he opposes such a good project ... since you are opposing the government of India you are an anti-national. (Majumdar and Lahirind)

The pro-dam group is led by Dzongu MLA ${ }^{9}$ Sonam Gyatso Lepcha, the sitting member of the ruling Sikkim Democratic Front (SDF) party. He describes the dams as a "harbinger of great economic boom." (Atreya 2007:8)

It is difficult to get a true picture of the motivations of the dam-supporters for the strongest voice in favour of the projects is the government or people closely connected to the government and the Dzongu MLA (who in 2009 became Sikkim's Power Minister). The pro-dam narratives of villagers quoted in the media are more or less identical to the government's pro-dam narrative of wealth, jobs, and progress for Sikkim. I asked two leading Gangtok-based journalists, who are familiar with both sides of the debate, for their views on the motivations of those who support the dams and who sold their land. Was it for the money? Was it an informed decision, do the landowners believe the projects will bring jobs and long-term prosperity? Or was it because they support SDF, the ruling party or fear 'victimisation' ${ }^{10}$ if they don't support the government? ${ }^{11}$ The editor of the English language daily NOW, Pema Wanchuk responded:

Of course it was for the money ... land rates in Dzongu are very low, with a pool of only Lepchas of Dzongu to sell to .,. the large cardamom plantations died out, so liquidity was an issue and the rates offered were too lavish to ignore easily." Wanchuk also mentioned that a major landowner is the Tholung Kazi ${ }^{12}$ who does not live in Dzongu and has no great use for the land. "An easy decision for him to be able to sell it away at much higher than market rates.

\footnotetext{
${ }^{9}$ Member Legislative Assembly of Sikkim

${ }^{10}$ In Sikkim the term victimisation is frequently used when describing 'punishment' meted out to people who oppose the government. Being 'victimised' usually means the dissenter or his relatives may be transferred to an inconvenient posting if they are a government worker, or lose government contracts if they are a supplier of goods and services.

${ }^{11}$ Responses from each received on emails dated 22 October 2009

12 Tholung is a village in Dzongu, Kazis are descendents from the old noble families of Sikkim who owned vast tracts of land.
} 
Wangchuk said the decision to sell land for the projects was not informed. "Of course it was not an informed decision. The Teesta Stave V experience notwithstanding, no one knows the impact of a hydel of any other project. Yes, they had a public hearing and published these studies, but these are neither circulated nor sought. His colleague ${ }^{13}$ agreed that the decision to sell was not informed.

People have land but no money so obviously the lure of hard cash was difficult to resist. The people here are too simple and gullible so it was easy to make them drink the kool-aid about how hydel projects would bring about jobs and schools and roads and make their lives more prosperous ... I don't think they were aware at all of the environment and culture price they may have to pay. More importantly, I don't think they could care less about that. When you are faced with poverty ... these concerns don't seem to matter as much.

She had heard that a significant amount of the land belonging to poor landowners was bought by richer landlords or other moneyed people ahead of the project and these are the people who actually benefited by selling the acquired land at a much higher price to the project developers.

Because Sikkimese people depend so much on government for their livelihood - the government is the biggest employer and the biggest buyer of goods and services - the relationship between the landowners to the government is already one of dependence. Wanchuk noted that SDF supporters would know that they would gain by way of influence and contracts and supply orders in the event of any big project. "Victimisation - perceived as well as suffered - definitely has a role to play and must have influenced some decisions." His colleague concurred: "there could have been some fear of victimisation too, which seems to influence most decisions in Sikkim," she said.

The promise of local jobs is persuasive in a place where job opportunities are scarce and most educated people leave Dzongu to work elsewhere in Sikkim, often in government jobs.

Dzongu villagers who are for the projects say the dams will bring development to the area and improve their lot. "Our children need jobs. Already our boys are getting

\footnotetext{
${ }^{13}$ I have not named my other informant as I am not clear that she wishes to be identified. She has broad and intimate knowledge of issues in Sikkim.
} 
unskilled jobs at project sites. Dzongu can’t remain in darkness forever," said Choden Lepcha, Dzongu's milk board chairman.

"I don't know much about environmental impact, but the government has assured us that the dams will be safe," said Kadzangmu Lepcha, a panchayat ${ }^{14}$ member in Dzongu's Passingdang village. "The projects will only do us good.” (Mitra 2008)

Jobs for the locals are looking doubtful however, if the performance of hydro companies on other private sector projects is any indication. At an investors' meet in Gangtok on October 12 2009, Chief Minister Chamling admonished private investors for violating the agreements signed with the State Government in relation to local employment. He cited the LANCO hydro power project at Singtem which has just 15 percent local employees and the CIPLA factory at Kumrek which had trained 140 local youth and then replaced them. "Those who have a tendency to stray away from agreements and take our people for a ride will have to bear the brunt of displeasure," said Chamling. (Sikkim Express 2009).

\section{Rural protests need a voice in the cities}

Dzongu's status as a reserve has had the effect of preserving Lepcha language and culture within the Lepcha community that lives there. However, the requirement for a permit to enter the reserve has also had the effect of shutting Dzongu away from people from outside. When the proposed projects came closer to being a reality, there were no first-hand knowledge or reference points for Sikkimese to draw on to examine their reaction to the projects. Though Sikkim is a small state, very few Sikkimese have visited Dzongu and even Lepchas from outside Dzongu must first obtain the special permit. Therefore, the Lepcha activists' voices were not heard outside the villages and in order to reach government decision makers and influencers such as the media, the activists would need to have a voice in the city.

The lack of a listener for the protester's voice is common in rural areas. In order to exploit the hydro-power of wild rivers, governments and developers are invariably led away from the cities to remote places without the physical and social infrastructure that

\footnotetext{
${ }^{14}$ A panchayat is an elected official who represents villagers' interests to district politicians.
} 
is required if the affected land-dwellers need to garner outside support for their position. Among rural movements, those with least access to a voice have often been the indigenous or tribal groups. Yet ownership of white water - commonly referred to as 'white gold' by dam proponents - is a shared issue among the tribal communities in Sikkim and nearby Indian north-east states. Ironically it is the very remoteness of these marginalized communities which has contributed to their retaining control over the headwaters of rivers which now seem like key locations for dams and hydroelectric development.

The respected journalist and editor of the Nepal-based magazine Himal, Kanak Mani Dixit noted that:

Adivasis and other marginalised communities of the hill regions have, by virtue of the terrain they inhabit, become the most proximate owners and custodians of the white water and renewal energy it represents. Like the Bedouins of Arabia, they suddenly find themselves holding on to this 'white gold', even as they as yet lack the capacity to defend their interests against the metropolitan demand. (Dixit 2007:21)

There are many examples of rural protests being played out in the cities. In New Delhi, it is common to see protesters from all over India at the old outdoor astronomical observatory, Jantar Mantar, near Parliament House. Many come from rural India, intent on having a voice in Parliament, even if just within the sightline of the politicians who decide their fate.

One of the highest profile anti-dam movements in India - the protest against the damming of the Narmada River, was conducted in rural areas, to support the adivasi communities that lived along the Narmada. However much of that protest also took place in several large Indian cities including New Delhi, Mumbai, and Bhopal, the capital of central Madhya Pradesh state and home of most of the quarter million, mainly indigenous people to be displaced by the four billion-U.S. dollar Sardar Sarovar dam. It was in Bhopal where activist Medha Patkar sat on one of several hunger strikes. ${ }^{15}$

In Australia, rural protests have similarly had to be fought in the cities. In Melbourne in 2005 , for example, 500 cattlemen and women of the high country rode their horses to Parliament House to protest the Victorian state government's policy to stop cattle grazing in the Australian Alps. (ABC TV 2005). Even more relevant, Australia's most

\footnotetext{
${ }^{15}$ For information on the Narmada protest go to http://www.narmada.org/resources/
} 
successful anti-dam protest, against the damming of the Franklin river in Tasmania, took place at the site of the dam - the Gordon and Franklin rivers in Tasmania, but influence was also applied in the cities. At the blockade of the Franklin River in December 1982, supporters held rallies in Sydney, Bendigo, Hobart, Launceston and outside Parliament House in Canberra. (The Wilderness Society 2008)

\section{The Shift to Gangtok increases ACT's reach}

In December 2006 after two years walking from village to village, meeting their fellow Dzongu Lepchas to discuss their objections to the projects, ACT shifted their protest to Gangtok to garner wider support. Gangtok is in East Sikkim, where Lepchas are just $4.89 \%$ of the population, Bhutias $14.1 \%$ and the remainder various communities of Nepali origin. (State Socio Economic Census 2006:67) The shift to Gangtok was not going to greatly increase ACT's support base of directly affected Dzongu Lepchas but would bring the movement into the geography where decisions are made about the projects by government. It was also important to have access to the media, for there are no media representatives based in Dzongu. Dawa Lepcha, said: "We decided on Gangtok as it is more apt for media attention as well as other publicity, and, to gain attention of the authorities and, to spread the protest to larger audience. ${ }^{16}$

I was present at the first major ACT-hosted public meeting in Gangtok on the 12th December, 2006 at BL House ${ }^{17}$, which was the $12^{\text {th }}$ anniversary of the ruling party's election victory. The initial intent was to hold a rally and candlelight vigil outside the state government building at Mintokgang, or at the Statue of Unity, which commemorates the treaty between the Lepcha Chief and Bhutia King which symbolises the formation of the Kingdom of Sikkim, but this was cancelled after the government asked for talks and the activists agreed, continuing instead with a public meeting.

Approximately 400 Lepchas attended the meeting. Many had made the difficult journey from Dzongu to hear the activists' perspective on what was happening to their land and to make their voices heard.

16 Email to Kerry Little 7 Nov 2008

17 BL House is used by the Bhutia and Lepcha communities for meetings and other cultural events. The Bhutia and Lepcha communities are often grouped together for it was these two ethnic groups which signed the first treaty to create the kingdom of Sikkim. Politically they often align to fight for their rights as 'first citizens' of Sikkim. 
After the meeting, organisers met with the Chief Minister of Sikkim who offered to review "every aspect" of North Sikkim hydro-electric projects and also expressed "deep concern"” for the people of North Sikkim "...that culture, tradition and identity would never be compromised for the sake of economic development alone."(Rai 2006:1) The story received blanket coverage in the Sikkim press the following day however the Chief Minister did not keep his promise and there was no review of the projects.

I was told by the activists that the $12^{\text {th }}$ of December 2006 was the day the movement gained momentum; a turning point in the campaign to stop the projects. However, it wasn't initially considered to be the first stage of a planned campaign. ACT's city campaign has developed in stages, more as a response to each consecutive action, rather than a forethought sequence of events. "I always considered it [the 12 Dec event] in Gangtok ... it was easy for the press, and for other people to see both from outside and within and as a result more attention and pressure on the government," Dawa Lepcha explained. "Also we would be in the capital and at the doorstep of the government and [Chief Minister] Chamling. I did not expect victory particularly that fast but I did expect something to happen early towards victory."

\section{The hunger strikes force a commitment to the city}

On the $20^{\text {th }}$ June 2007 after six months of inaction by the state government, the activists took decisive action.

Dawa Lepcha and his young friend, 22 year old college student Tenzing Lepcha sat in front of BL House and started an indefinite hunger strike that gripped Sikkim for 63 days and spread news of the protest beyond Sikkim's borders. Their hunger strike was, like many protests in India, contextualised in the spirit of Gandhian non-violent protest but not to the extreme of 'Crusading Gandhian' described by Guha. ${ }^{18}$

At the time, the activists thought the hunger strike would be quickly successful. However it lingered for several weeks and sparked a continuous, symbolic, relay hunger strike outside BL House.

\footnotetext{
${ }^{18}$ Swain A, (1997) Democratic Consolidation, Environmental Movements in India, Asian Survey, Vol 3, No 9, pub. University of California Press:828
} 
The Sikkim newspapers ran daily reports on the progress of the first hunger strike and continued to report over the next weeks as others--young and old, from all over Sikkim- joined the movement, many alternating between BL House and the emergency ward of Gangtok's hospital. Outside BL House, sitting with Dawa and Tenzing the 'relay' hunger strikers sat for short periods of time in support.

The hunger strike served many purposes. It galvanised Lepcha youth, and many young Lepchas left their studies and their village duties and moved to BL House to fight against the projects; it increased the supporter base of ACT, for the sacrifice of Dawa and Tenzing as the hunger strike continued brought many people to Gangtok to pay their respects; it very quickly raised the profile of ACT beyond that of a small, villagebased group of dissenters to a large (for Sikkim), courageous and at some points powerful group with a clear charter and message.

The symbolic relay hunger strike continued to place pressure on the government as did the ailing health of Dawa and Tenzing. Prayers were performed by Buddhist lamas, Hindu priests, Lepcha shamans and the Lepcha Bishop of Darjeeling district at BL House. The powerful Tarang Bongthing was brought from his village in Lower Dzongu to BL House to perform prayers for Dzongu. He was photographed by the media and by foreign tourists who may have, as his neighbour mused when hearing of their interest, been fascinated by him "because he is a very rare species."19

The Lepchas made BL House their city headquarters and Gangtok home. Young men slept upstairs, on beds made by pushing chairs together. The walls were adorned with maps, photographs and narratives explaining the protests and the damage they will do. There was an area set aside as a kitchen and those not sitting outside on relay hungerstrike eat together every night; food often donated by supporters.

The Lepchas' hunger strike was the major news story in Gangtok. This created tension in official circles which accelerated to the point where the government demanded ACT stop the hunger strike or that they would use force to remove them from BL House. At various stages of the protest there have been threats and arrests - notably the arrest of several Lepchas who refused to stop a march to Gandhi's statue on the occasion of his birth anniversary. There were also petty harassments: an officer from the Sikkim Intelligence Bureau visited BL House each day and photographed the activists. Another officer sat across the street charged with noting details of visitors and activity there. The

\footnotetext{
${ }^{19}$ Atuk's neighbor Thendup translated my interview with Atuk, The Tarang Bongthing, on 7 Jan 2009
} 
electricity was turned off, the power department suddenly producing an invoice for several years' electricity and demanding payment. For village Lepchas used to patchy power arrangements, this was a hiccup rather than a hardship. It meant, however, that the computer needed for all official correspondence could not be used.

The shift to the city for the activists increased their profile but also exposed them to farcical side issues. The opposition parties seized the protest as their own and used the Lepcha protest as part of their anti-government narrative. They 'burned in effigy' the governor of Sikkim, resulting in the arrest of 40 and jailing of 25 members of the opposition Congress party. The opposition parties' involvement enabled the government to claim the protest against the hydels was a political issue and condescended that 'the innocent Lepchas were being misled by the opposition parties for baking their political bread. ${ }^{20}$

The opposition politicians' anti-government rhetoric - and the government's response was starting to overpower the activists' message and they had to formally distance themselves from the politics by releasing a media statement that they were acting independently from the opposition parties.

The Sikkim government repeatedly called for the strike to end but Dawa and Tenzing, in hospital and weakened by their action refused to stop. The Chief Minister promised to "protect the sanctity of Dzongu at all costs" ${ }^{21}$ but the activists, mindful of his broken promise of December 12 2006, refused to stop the hunger strike on his word alone. They demanded an independent review of the projects.

The number of ACT's members and supporters grew. Tibet Road became a place of pilgrimage for Lepchas - with BL House a symbolic Dzongu. Offerings were left there for the hunger strikers, the activists and the deities.

The Lepchas' habitation of BL House was so complete that I jokingly referred to it as the Lepcha Embassy for it had become a type of Lepcha homeland, a satellite Dzongu if you like, for the youth shuttle back and forth between their villages and the city, trying to satisfy the demands of sitting on relay hunger strike, working for ACT and fulfilling family responsibilities. A core group of around 12 youth lived there all the time. When not sitting on relay hunger strike or supporting ACT's programs, they watched TV, played indoor cricket and a board game called Carrum.

\footnotetext{
${ }^{20}$ Sikkim Times 2007 www.sikkimnews.blogspot.com (accessed 20 October 2009)

${ }^{21}$ This was a recurring statement by the Chief Minister, widely reported in Sikkim.
} 
These Lepcha youth are the foot soldiers for ACT. Some would be in college if they were not at BL House, or in their village tending the families' cardamom crop. They stay loyal to the movement and close to Dawa and Tenzing whose sacrifice they admire and respect. Their rural background is an important part of their narrative and being from Dzongu brings with it a collective identity that imbues loyalty and strengthens the group.

At times, the building has served as a kind of 'sovereign land', a symbolic Dzongu incongruous though its concrete bones are as a substitute for the lush forests of the Lepcha homeland.

On the 21st August, two months after they started their fast, Dawa and Tenzing sipped orange juice and exchanged the bitter taste of political posturing - which had marked their 63 day hunger strike - with the sweet taste of love and respect that filled the hospital ward in Gangtok. They had broken their hunger strike because the Government bowed to pressure and promised to review the projects and the Chief Minister appealed for the strike to end.

Their relay strike continued with the goal of ending it completely only if the government started a review of the projects. This review committee was, however, formed with a scope for the implementation of the projects, instead of the expected review of the proposal. The activists called for a correct review of the projects as a whole. But nothing happened.

So seven months later they started a second 'indefinite' hunger strike in March 2008. Very soon after - for their kidneys had barely recovered from the first time - they were back in hospital and back on the feeding tubes. I was in Gangtok in April 2008, shortly after the start of the second hunger strike. I visited the hospital which had become a second 'BL House' for wherever Dawa was, the movement was. Another activist, Ongchuk Lepcha, joined Dawa and Tenzing for the second strike and the three of them were placed alone in a ward--wedged between the noisy nurses' station and the emergency room--where they stayed for 90 days. There, sitting feebly on his hospital cot, Dawa ran a satellite ACT headquarters. He wrote press releases and letters and received visitors including supporters, associates, NGOs, media and his family. He also prayed, closing his eyes to the wails of children and ravings of drunks through the 
swinging doors to the ward next door. Always hovering was Dawa's younger brother Ongel, who poured juice or Horlicks into the men's feeding tubes ${ }^{22}$ and assisted them to walk to the toilet for they were too weak to leave their room unassisted.

The second hunger strike served to re-mobilise the movement. The media story had shifted from page one lead to a lesser story and the government seemed to be following a strategy of ignoring the protestors until their funds or resolve ran out. Quiet weeks where the battle seems stagnant can be demoralizing for the members and the second hunger strike injected renewed energy and belief to the young men and women who work for the movement.

The hunger strikes served to make Gangtok home base for the activists. Dawa Lepcha said the end of the first hunger strike - when nothing came forth of the assurance from [Chief Minister] Chamling - was when he realised that victory would not come quickly. "We chose not to move back to Dzongu because it would not have brought much improvement and with the [challenge of] the permit and all it would not have added much. BL House will be the nucleus as long as we continue with the movement," he said. $^{23}$

\section{The hunger strike attracts outsider support}

The 2007 hunger strike had attracted many supporters. On the first day there were three Lepchas out the front of BL House, by the third day, there were six; by the eighth day-ten. The local media reported that two national television news media travelled to Sikkim to cover the protest, a boost to the protestors who had successfully moved news of their protest beyond their region. It brought to Sikkim the well-organised West Bengal Lepchas who, inspired by the hunger strike and with a mandate of cultural revival, joined the fight to save the Lepchas' "motherland". Seven hundred Lepchas from West Bengal cut off Sikkim's lifeline to the rest of India by staging a blockade on the national highway. Dorjee Lepcha from the Kalimpong Lepcha Youth Association in West Bengal was quoted saying: "Dzongu is sacred to us and any attempts to destroy it

\footnotetext{
${ }^{22}$ The hunger strikers were placed on Ryle's Tube in order to keep them alive when their kidney function became dangerous. It is illegal in Sikkim to commit suicide and they were told they either submit to Ryle's Tube or would be sent to Siliguri Hospital which is four hours drive away across the border.

${ }^{23}$ Email to Kerry Little dated 22 October 2009
} 
will have to be stopped." ${ }^{24}$ Weeks later 4,000 Lepchas and supporters marched in Darjeeling. They then started their own hunger strikes in Darjeeling and Kalimpong.

The movement had shifted from its humble beginnings in a Dzongu village and spread across the state border. The support of the West Bengal Lepchas had not been envisaged in the early stages of the movement by ACT, but as Dzongu is the motherland for Lepchas everywhere, their support was appropriate and welcomed.

The involvement of the West Bengal Lepchas elevated the pressure on the government and gave ACT much needed resources. The West Bengal Lepchas have connections in government circles in New Delhi for they have long campaigned for Lepcha language to be officially recognised by the West Bengal state government ${ }^{25}$. During the first hunger strike they held a protest in New Delhi and soon after an 18-member delegation of antidam representatives from Sikkim and West Bengal made the first of what have become many meetings, with media, ministers and NGOs in New Delhi.

The New Delhi connections are important, for the activists believe that without central government intervention the projects will not be stopped in Sikkim. "After the hunger strike, we started seeing that it was necessary to do it [go to New Delhi], and bring attention to the central authorities," said Dawa Lepcha.

ACT has received support from several influential NGOs including Kalpavriksh, an environmental action and research group in India; from International Rivers, a global organisation whose mission is to protect rivers and defend the rights of communities that depend on them and from other NGOs which have given their support on the ground in Dzongu. This has brought new voices, at times from engineers, environmental consultants and scientists whose geographical independence and ability to contribute informed commentary on the damage that the dams would bring, has helped to validate ACT's arguments.

In May 2008, a two day tour to study the impact of hydro-electric projects in North Sikkim was undertaken by a six member team of NGO representatives, under the banner of Independent Committee on Big Hydro Projects of Sikkim.

\footnotetext{
${ }^{24}$ Development slur on green guardian, The Telegraph, 22 March 07, accessed 3/10/07)

${ }^{25}$ Lepcha language is recognised in Sikkim and taught in schools. The West Bengal Lepchas have not yet achieved their aim to have the same recognition in their state.
} 
The committee members came from SANDRP (South Asia Network on Dams, Rivers \& People) Delhi, from the National Forum of Forest People \& Forest Workers Delhi, from the Rural Volunteers Centre in Assam, the North Eastern Centre for Environmental Research and Development in Guwahati, Matu Jan Sangathan, Delhi and from Nespon, Siliguri.

The committee visited project sites at the 510 MW Teesta Stage V Project at Dikchu, the 1200 MW Teesta Stage III Project under construction in Chungthang and the 280 MW Panan Project coming up in Dzongu near Passingdang. The committee's findings were widely reported by the media. The committee asked the government to suspend the Panan for five years and to take up small hydro projects instead:

Broadly, we see that the Sikkim government, partly under pressure from the central govt, has hastily committed itself to develop large number (42 on last count) of big hydropower projects, without much consultation with Sikkim citizens, without considering the implications of the projects for the local people, environment, culture, future generations and even return on investment for the state and the people. It has also not seriously assessed the options available for electricity generation or options for development in general. This is evident in the way the Teesta V has been developed, the way Panan HEP MOU has been signed and Teesta III implementation has started. ${ }^{26}$

Outsider support also came from the prominent Indian social activist Medha Patkar, best known for her protests against the dams in India's Narmada valley. She came to Gangtok in April 2008, during the second hunger strike, and stayed for no longer than 12 hours (including overnight) yet her presence was a watershed for ACT and the movement for her fame gave the protest legitimacy beyond Sikkim's borders.

Medha Patkar spoke convincingly and passionately against the Dzongu projects to a large contingent of media at BL House then shifted her focus to the hospital where she greeted Dawa, Ongchuk and Tenzing, placing her hand on the forehead of each, enquiring about their health, their treatment, and their progress in relation to the movement. Her visit was a morale booster for the hunger strikers and the members and supporters of ACT, who were dejected by the abandoning of the West Bengal Lepchas' long march the day before.

\footnotetext{
26 http://weepingsikkim.blogspot.com/2008/05/79-days-hungryindependent-commitee.html
} 
The next day the State Government claimed her support for the Lepcha activists was "politically motivated at the instance [sic] of the opposition parties" and that she "has always been against the development and prosperity of the country.,"27

Her visit to Gangtok caused a brief sensation but her enduring help to the Lepcha activists lies with her connections in New Delhi which, after the April visit, she made available to the Lepchas. She has taken up their protest, along with the many others she works for and provides an influential voice in government and NGO circles. Soon after her visit, she invited ACT to join a Dharna [protest] being held at Jantar Mantar in New Delhi to protest the "Displacement \& Un-Democratic, Unjust, Anti-People \& ProCorporate 'Land Acquisition (Amendment) Act, 2007' and 'Resettlement and Rehabilitation Bill, 2007'”. Loden G Lepcha from Passingdang led a small delegation to the capital where they met with several NGOs who support ACT and give them a voice in New Delhi.

\section{Technology crosses more borders}

While the to-ing and fro-ing between ACT and the government continued, the drama was played out daily on a blog - weepingsikkim.blogspot.com. Support from elsewhere in India and around the world was posted to the blog, giving the activists a much needed morale boost and the attention they sought by moving the protest to Gangtok. The blogger could not have done the same work from Dzongu as connectivity there is poor, and much of the content on the blog came from other media reports.

Sikkimese living outside India posted their support on the blog and supporters in Sydney (to whom I had sent information) gathered and were photographed holding 'save the teesta' banners against the backdrop of the harbour bridge. The photo appeared on the front page of Sikkim daily newspapers, in the magazine Talk Himalaya and the blog. This photo inspired a similar morale boosting photo taken in Melbourne, with Sikkimese and Australian Indigenous elders showing their support for ACT. Information on the blog has informed media articles, academic papers and other blogs. Perhaps the widest coverage received from the blog is a story on the hunger strike and

\footnotetext{
${ }^{27}$ SDF lashes out at Medha Patkar, The Statesman April 19, 2008, p.5
} 
link to the blog on the front page of the Sikkim chapter in the latest edition of The Rough Guide to India. ${ }^{28}$

Creating a blog was not part of ACT's protest strategy, nor was it created by ACT, but it has helped to broaden the support base enormously. The blogger is a non-Lepcha Sikkimese youth who is concerned about the hydel policy in Sikkim and views the impact of hydro-electric power projects in the state as a 'Sikkim issue' not a 'Lepcha issue'. His support and work was to be crucial in getting the word out about the movement. The blog was live for some time before the Sikkim state government learnt of it. Sikkim's Chief Minister (who I heard was shown it by his son) described the blog during his speech in front of thousands on the occasion of India's $60^{\text {th }}$ anniversary of independence as: "cyber warfare" and threatened the blogger by stating that the police and army would be deployed to track down the blogger and charge him for anti-national activities. This threat was never carried out however the blogger has since passed on the day-to-day updating of the blog to members of ACT.

The blogger and his friends posted videos of Dawa and Tenzing in hospital on YouTube, a story that was picked up by the influential UK Independent newspaper. $B B C$ World online also ran the story. The use of technology to capture an audience beyond the villages and the city of Gangtok, even though not in ACT's initial plans, has served the movement well. ACT members have developed the skills to update the blog and YouTube with films about the protest which have also been posted on International Rivers' and other NGO websites. Technology has taken the movement global, albeit in a small way, but a small rural activist group could not have captured the attention of so many people without it.

\section{Back to the villages to protect the future}

By late 2008, the media's enthusiasm for the story appeared to have waned, although ACT's press releases continued to get a hearing in most of the Gangtok papers. The blog is still live but now updated sporadically. The youth who sit out the front on relay hunger strike had started to resemble a kind of wallpaper on Tibet Road, its pattern one that passers-by had become so used to they barely noticed it.

\footnotetext{
${ }^{28}$ The Rough Guide to India is published by Rough Guides and distributed worldwide by Penguin Publishing. www.roughguides.co.uk
} 
At the 500 day anniversary of the first hunger strike, on November $2^{\text {nd }} 2008$, Dawa Lepcha informed the media that there would be a change in strategy: ACT was thinking of devising a new way to protest against the mega hydroelectric projects. "Our members will be meeting soon and we will decide on the new plans which we will inform", he said in a press release. ${ }^{29}$ They have, he told me, achieved what they wanted to achieve by "putting up in Gangtok" and their achievements are laudable. Four of the six Dzongu projects have been shelved with Letters of Intent between the government and developers withdrawn. This was achieved during Dawa and Tenzing's the first indefinite hunger strike however ACT had fought on, determined to stop the other two Dzongu projects.

Throughout the campaign the relay hunger strikers had remained at BL House, a symbolic umbilical cord linking the protestors in the city and their counterparts in the villages. After Dawa Lepcha's $500^{\text {th }}$ day announcement, the day to day running of the movement moved to the villages where he also returned. Their Delhi connections made, ACT continue to go back and forth to seek help from central government members and NGOs there. There are also petitions brought by ACT due to be heard in the Supreme Court in New Delhi.

The Lepchas may be strengthened by the environment they return to for, while they went to the city seeking justice, they had always said that it was in nature that they had found inspiration and energy for the rest of their fight.

The activists' focus continues to be on the 280MW Panan project near Passingdang in Upper Dzongu and the 495MW Teesta Stage IV project near Hee Gyatang in Lower Dzongu. In order to succeed, however, it is imperative that public opinion in the villages is with them. Their shift to Gangtok during 2007 and 2008 while essential, took them away from their people. There are hard feelings among friends and families who have differing views on the future of Dzongu. There is persuading to be done there - and educating - and rebuilding of relationships. An information campaign through the media won't connect in the villages where newspapers are a rarity. Communicating needs to be personal and for that, the activists need to be back home.

\footnotetext{
${ }^{29}$ Posted on weepingsikkim.blogspot.com (accessed 19 December 2009)
} 
There is also motivating to be done. Lofland ${ }^{30}$ has addressed the issue of "membership maintenance" as a problem for social movement organisations and while the dedication of the young foot soldiers may never be in doubt, they must be actively deployed; their energy used to further the needs of the movement. Campaigning in the villages puts them inside the land they are fighting for and back with their family support structure. And so they have returned there, back to their people, their language and their culture. Since the beginning of 2009 they have held meetings in the villages, to take their message to the community and to try to persuade land owners not to sell. At these meetings they share current issues relating to the dams: the latest happenings in relation to the Ministry of Environment and Forest, the faulty Land Acquisition processes, and what ACT claim to be other illegal matters. The meetings are well attended and are supported by new cultural symbols. At each meeting ACT flies their Lepcha flag and they play a campaign song, Lyang Arey, meaning 'this land', written by an ACT member while sitting on hunger strike outside BL House and sung mournfully by his teenage brother. The song implores Lepchas to take care of their land, to protect it and not sleep when they should be fighting for their motherland. Sherap Lepcha told me he cried when he first heard this song:

"I was so moved by this song...we have lost everything now, our land has been taken ... and Dzongu is the only place where our Lepcha people are living together ... We are going back to the forest, back to where we started ... if they take this land also then we have nowhere to go. So this is why we have been fighting against this hydel power project ... so this song really means a lot to us. We have to unite." 31

In February 2009 ACT took action in response to a violation of guidelines of Ministry of Environment and Forests (MoEF) by the Panan project developers. Labourers are not allowed to stay back in Dzongu and must leave at the end of each working day however ACT claimed that at least 20 workers were staying in Dzongu in sheds built at the Panan dam site by the hydro company 'in blatant violation of the Clearance Condition of the MoEF ${ }^{32}$. Members of ACT visited the site and destroyed the sheds, resulting in the arrest of 43 members including Dawa and Tenzing. They were in jail for one month before being released on strict bail conditions which included not visiting any dam site in Dzongu region. Dawa Lepcha's bail conditions required him to stay in Dzongu most

\footnotetext{
${ }^{30}$ Lofland (1996) cited in Jasper J, The Emotions of Protest: Affective and Reactive Emotions in and around Social Movements, Sociological Forum, Vol 13, No 3, (Sep 1998)

${ }^{31}$ I interviewed Sherap Lepcha on 14 January 2009 in Gangtok.

32 (weepingsikkim 2009) (accessed 19 December 2009)
} 
of the time, leaving for no more than ten days at a time. My correspondence with them during this time reflects an upbeat mood. A mobile phone text message from one committee member (not in jail) in answer to my enquiry relating their well-being states: "...we may get bail on $8^{\text {th }}$. All our heros [sic] $r$ very well $\mathrm{n}$ happy in jail." This is confirmed by another who upon his release wrote “... All of us there got a good experience."

\section{Conclusion}

Twice a day, from the North Sikkim taxi stand next to the Vajra Cinema at Baluwakhani in Gangtok a jeep goes to Passingdang from Gangtok and back again. It costs just 100 rupees and is loaded (at times over-loaded) with people, food, household goods and gossip. It is a 70 kilometre journey which takes at least three hours because the jeep rarely moves out of third gear while it travels the steep, often bumpy road to North Sikkim. And, while it shuttles between the city and the village, its passengers talk. Sometimes the talk is light; benign stories passed on with laughter and good humour. Other times it is political, the hydels being the most controversial issue in North Sikkim. I have been advised by friends in ACT not to mention the hydels while travelling in the taxi, or in Dzongu, for it is an emotionally charged subject.

The most recent news from Gangtok is that the government has invited ACT to talk about a resolution. As a sign of good faith, ACT stopped the relay hunger strike on September 272009 and a meeting with the government was held soon-after. Sikkim's Chief Minister said he had "never intended to hurt the sentiments of the people of Dzongu, North Sikkim with the mega power projects ... developmental activities have been ushered in ... with the objectives of making Sikkim economically self-reliant and giving tempo to the ongoing socio-economic development of the start."

The issues relating to the dams are not yet resolved but the door has opened a crack perhaps there will be agreement on the future of Dzongu. A cynical response, which I have heard from two people (one within ACT and one outside) is that the MoEF has, more than once, refused the Sikkim state government's submission to reconsider

\footnotetext{
${ }^{33}$ Sikkim Express (2009) Govt, ACT in dialogue mode finally, Let us collectively search for solutions: SM, 13 October 2009. www.sikkimexpress.com (accessed 17 October 2009)
} 
allowing some previously refused projects in North Sikkim and the government is hoping to negotiate an outcome direct with ACT.

The battle for Dzongu continues despite the recent thawing of the relationship between ACT and the Sikkim government. During the past few years the group of inexperienced, possibly idealistic, Lepcha youth have become experienced campaigners. Their relay hunger strike continued for 915 days and while the banners, khadas and hunger strikers no longer adorn the grey, concrete facade of BL House, they can be redeployed immediately if needed.

The activists are, not surprisingly, better organised than when they started out: they plan their campaigns and plan for a variety of scenarios. They have strong contacts in New Delhi; they have gained a sophisticated understanding of the processes of state government and learned how to exploit the gaps in these processes.

They are able to act quickly because mobile connectivity has brought them closer, improving the speed of communications. They also communicate regularly to their support base outside Sikkim via the blog.

The battle for Dzongu has, for some young Lepchas, changed their perceptions of their homeland: it has brought the gift of clarity and confidence that they can improve the lives of Dzongu Lepchas. They view their motherland through a different lens, in many ways a more sophisticated lens. Their appreciation of village life - even for those who left the village many years earlier - is illuminated by the threat of losing it. They make plans for a Dzongu that will bring job opportunities for Lepcha youth in eco-tourism and organic farming. They talk about providing schools in Dzongu that will provide a better education that that currently available at government schools. Many of the Lepcha youth who work with ACT have received an environmental and cultural education during the protest. They know more about their history, their culture, their language. They talk about global issues like capitalism, globalisation and climate change.

Their move from the villages of Dzongu to the cities of Gangtok and New Delhi has served their protest well. It has given them a voice in the places that decisions are made. It has also toughened them. They don't fit the somewhat clichéd image of timid 
Lepchas; the 'forest-dwelling fairy worshippers' (Plasier nd) as described by the British colonists. They are warriors now - battle-worn, battle-hardened and want to trust the motivations of a government which has asked them to talk.

However, they know that complacency in the face of reconciliation with the government can expose them and their Dzongu. While the proposed talks are signs of progress, they will keep a watchful eye on development activity north of the Sankalang Bridge.

The quiet villages of Dzongu, 'Ney Mayel Lyang' are now rich with modern stories - of courage and cowardice, politics and intrigue, naiveté and stubbornness, of families split apart because of differing views on the future of their Dzongu. This 'land of hidden paradise' has been forever changed. If the dams are built, the landscape will be scarred with the concrete bones of large infrastructure and the Teesta River's journey will be hampered by a most unnatural force. If not, it is expected that the landowners will keep their compensation so their loss will not be financial.

But whether the dams are built or not, relationships between some families, friends and neighbours have been destroyed by the battle and people will need to find a common space they can inhabit without recourse. If they can't then there are no winners in the battle for Dzongu.

In the city, where much of the battle took place, no-one will see the projects, nor notice the torn lives of a community fragmented by their construction. 


\section{Bibliography}

ABC Television, Australia http://www.abc.net.au/worldtoday/content/2005/s1388509.htm

Arora V (2008) "In the name of development, do not make us refugees in our own homeland." Contestations around Public Interest and Development Planning Sikkim, India

Atreya S, (2007) Show of Strength by all at Panam Hearing, Midweek, pub. Mita Zulka, 20-26 Sep 07

Baviskar A (1997) In the Belly of the River, pub. Oxford India, Delhi

Dharmadhikary S, (2007) Have river, will dam, HIMAL SOUTHASIAN, September 2007.

Dixit, K M, (2007) Big dams in Southasia, The dangers of inevitability, Himal, September 2007

Guha R (1988) cited in Swain A, (1997) Democratic Consolidation, Environmental Movements in India, Asian Survey, Vol 3, No 9, pub. University of California Press, p. 828

Lofland (1996) cited in Jasper J, The Emotions of Protest: Affective and Reactive Emotions in and around Social Movements, Sociological Forum, Vol 13, No 3, (Sep 1998)

Majumdar and Lahiri, (2007) Mayel Lyang Sut Lom, posted on http://www.internationalrivers.org/en/mayel-lyang-sut-lom-voices-hidden-land (accessed 17 October 2009)

Mitra M, (2008) Rift Valley, Down to Earth, http://www.downtoearth.org.in/full6.asp? foldername $=20081115 \&$ filename $=$ inv \&sid=1\&page=1\&sec_id=14 (accessed 17 October 2009$)$

Plasier, H (nd) http://www.iias.nl/iiasn/iiasn3/general/cnws.txt (accessed 22 October, 2009)

Rai, Remuna, CM offers to review 'every aspect' of North Sikkim, NOW! Daily, 13 December, 2006. p.1

Sikkim Express (2009) Private sector comes under heavy fire from Chamling, 13 October 2009

Sikkim Express (2009) Govt, ACT in dialogue mode finally, Let us collectively search for solutions: SM, 13 October 2009. www.sikkimexpress.com (accessed 17 October 2009)

Sikkim Times (2007) www.sikkimnews.blogspot.com (accessed 20 October 09)

Sharma, Deepak (2007) Dzongu residents and landowners endorse hydel options, NOW! 9 July 2007

State Socio Economic Census, (2006) Department of Economics, Statistics, Monitoring \& Evaluation, Government of Sikkim, pp 61, 64, 67.

The Statesman, March to Dzongu aborted, The Statesman, April 17 2008, p. 10

The Statesman, SDF lashes out at Medha Patkar, April 19, 2008, p.5

The Statesman, Sikkim protests against hydel projects, 25 January 2006. (acc 22/1/07) 
Swain A, (1997) Democratic Consolidation, Environmental Movements in India, Asian Survey, Vol 3, No 9, pub. University of California Press.

The Telegraph, 21 July 2004, Panel to oppose hydel project, (accessed 20/1/07)

The Telegraph, Panel to oppose hydel project, 21 July 2004, (accessed 20/1/07)

The Telegraph, Development slur on green guardian, 22 March 07, (accessed 3/10/07)

The Wilderness Society, http://www.wilderness.org.au/articles/frankin-river-campaignpart4

Weepingsikkim (accessed 18 April 2009)

Wangchuk, Pema Dorjee (2007) Lepchas and their Hydel Protest, Bulletin of Tibetology, pub: Namgyal Institute of Tibetology, Sikkim,

Zulca, (2007) Protest in the Hills, Talk Himalaya, Vol 1. No 1. July-Aug 2007, pub: Little Kingdom 